\title{
FUNCIONES DEL DOBLE EN LA NARRATIVA DE VIRGILIO PIÑERA
}

\author{
POR \\ GABRIELLA IBIETA \\ St. Joseph's University
}

"Cuando el señor $\mathrm{X}$ cumplió cincuenta años, decidió, después de pensarlo mucho, hacerse de otro yo. No sería ciertamente el alter ego que suelen usar los escritores en sus narraciones, sino una exacta reproducción de sí mismo.» Así comienza «El otro yo», texto que refleja uno de los obsesivos y recurrentes temas en la narrativa de Virgilio Piñera: el tema del doble. El presente ensayo analiza este tema en siete de sus cuentos, escritos entre 1944 y 1967, y en su novela La carne de René (1952). A manera de coda se discutirá «El otro yo» (1976), publicado póstumamente en 1987.

En su introducción a una antología de cuentos que integran el tema del doble, Albert Guerard explica lo siguiente:

The word double is embarrasingly vague, as used in literary criticism. It need not imply autoscopic hallucination or even close physical resemblance... Characters who seem occulty connected in the author's imagination... may also be referred to as doubles... A strong feeling of sympathetic identification may lead to a sense of doubleness, an immobilizing recognition of the self one might have been '.

En el caso de Piñera, los desplazamientos del doble ocurren de manera natural; el doble se manifiesta implícitamente (como en algunos de los cuentos) o explícitamente (como en La carne de René), y su función principal es producir en el lector un estado de sorpresa, de conmoción, incluso de desazón y desagrado. No es casualidad que uno de los escritores

\footnotetext{
' Stories of The Double (Nueva York: Lippincott, 1967), p. 3.
} 
que más influyeron en la formación literaria de Piñera fuera Kafka ${ }^{2}$. En un ensayo de los años cuarenta, «El secreto de Kafka», Piñera le rinde homenaje a este escritor, e identificándose con él, expone lo que se podría denominar como su propio credo estético:

En el campo de lo estrictamente literario, el único móvil del artista es producir, a través de una expresión nueva, ese imponderable que espera todo lector y que se llama la «sorpresa literaria»; la sorpresa por invención, lo mismo que un asesino que conseguiría su objetivo mediante la muerte por envenenamiento, o del espía por traición ${ }^{3}$.

El concepto de la literatura como agresión, típico de la literatura del absurdo, adquiere tal grado de perfección, que el lector (o por lo menos este lector) siente a veces la necesidad de defenderse, de cerrar el libro, de descartar las perturbadoras imágenes conjuradas por el torturado escritor. Sin embargo, el humor, la ironía, el distanciamiento estético y el absoluto control que ejerce Piñera sobre su material, nos permiten incorporar su realidad a la nuestra. Como sugiere Cintio Vitier: «Se trata de una voz que ha de salir... de lo vano y cóncavo de una máscara, de un resonador, no de un pecho desahogado y libre; pero esa oquedad y falsía responden sobre todo a la condición y exigencias de lo que debe testificar, que no es un paisaje, ni una soledad, ni siquiera un abismo, sino rigurosamente un vacío» ${ }^{4}$.

Tal apreciación, perceptiva y literaria, identifica indirectamente la presencia de lo doble en la obra de Piñera; en este contexto, las palabras «máscara» $\mathrm{y}$ «falsía» describen aspectos esenciales de su estética. Respecto de un texto clave del romanticismo europeo, Heinrich von Ofterdingen, de Novalis, opina Piñera: «... es una de las pocas veces que se ha usado la tosca realidad cotidiana como un fondo, como unas bambalinas, para que sobre él sucedan esas cosas de là verdadera realidad que se oculta tan celosamente.» Más adelante, sitúa a Kafka en esta misma tradición: «Es el mismo método de Kafka, su mismo secreto... En él, ficción e invención adquieren proporciones infinitas, de modo tal que las cargas de actualidad se hacen también función e invención» ${ }^{5}$.

Es curioso señalar aquí que, unos veinte años más tarde, Piñera tendría

2 «El nombre de Virgilio Piñera... hace años que se asocia en Cuba al del escritor judeo-checoslovaco de lengua alemana Franz Kafka. Virgilio Piñera ha naturalizado a Kafka entre nosotros...» (Rogelio Llopis, reseña de Pequeñas maniobras, en Casa de las Américas, 4, núm. 24 [enero-abril 1964], p. 107).

${ }^{3}$ Orígenes, 2, núm. 2 (invierno 1945), p. 42.

4 «Virgilio Pinera: poesía y prosa», Orígenes, 2, núm. 5 (primavera 1945), p. 48.

5 «El secreto de Kafka» (véase nota núm. 3), p. 45. 
que justificar sus puntos de vista respecto de lo «absurdo» de su obra en medio de realidades apremiantes. En 1967, el escritor provee una clave «realista» a uno de sus cuentos, en el cual la autoantropofagia asegura la supervivencia de un pueblo hambriento: "La carne" no es otra cosa que la protesta por los envíos de nuestras reses a Estados Unidos en la Segunda Guerra Mundial... De paso diré que estoy satisfecho de haberlo escrito partiendo de esa vilipendiada literatura del absurdo, que es tan realista como la realista» ${ }^{6}$. Respecto de la multiplicidad de significados y niveles en la narrativa de Piñera, a la cual ya se ha aludido, es importante citar la evaluación de Raimundo Lazo en su Historia de la literatura cubana:

El cuentista se independiza del nexo de una acción definida y da vida a personajes concretos y a hechos precisos, en un mundo de la más libre fantasía, en el que, a despecho de todas las audacias imaginativas, todo se dice, se dispone y se presenta sencillamente... Al margen de lo narrativo, el autor observa, especula, ironiza, describe y teje diálogos intencionados, y el relato es socialmente viable al ofrecer doble posibilidad de captación: la de la trama de insospechable discurso para el gran público y la de la creación imaginativa y sus proyecciones para el lector más atento y avisado ${ }^{7}$.

Y es precisamente de esta manera como Piñera resuelve las dificultades técnicas que presenta el tema del doble en la literatura. En un estudio dedicado al mismo, Robert Rogers sugiere que el escritor moderno trasciende los límites impuestos por la representación «obvia» de los dobles de la siguiente manera: "One way of generating a measure of compensating ambiguity... is to complicate technique, to make the formal features of the work as intricate as possible. What Borges and others have done... is to elaborate their technique to the point of self-parody.» Tomando como punto de partida la definición de Borges del barroco («The Baroque is that style which deliberately exhausts or tries to exhaust its possibilities and borders on its own caricature»), Rogers codifica el término «dobles barrocos» para analizar la presencia y función del doble en obras autorreflexivas como Despair, de Nabokov, y End of the Road, de John Barth ${ }^{8}$. Rogers usa un término psicoanalítico, en inglés decomposition, para expresar la fragmentación, ya sea doble o múltiple, del personaje literario, y explica que tal técnica opera como un distanciamiento que permite al lector aceptar

${ }^{6}$ Citado por Rogelio Llopis, «Recuento fantástico», Casa de las Américas, 7, núm. 42 (mayo-junio 1967), pp. 150-151.

(México: UNAM, Textos Universitarios, 1974), p. 280.

${ }^{8}$ A Psychoanalytic Study of The Double in Literature (Detroit: Wayne State Univ., 1970), pp. 162-163. 
los códigos establecidos por el escritor; una de las funciones de la fragmentación (o decomposition) es la distorsión:

In essence, the author must distort, or censor, his own productions. He cannot - perhaps he should not- be fully cognizant of all of their psychological implications. By the same token, the reader (at least the nonanalytic one) should receive a large portion of the work's meaning unconsciously, and the distortion of the fantasy content of a work by a host of defensive techniques..., of which decomposition is an important and complex one, enables him to register unconsciously what he could not easily confront in all its naked glory ${ }^{9}$.

Se podría sugerir que los dobles de Piñera son también «dobles barrocos». A través de distorsiones y desfiguraciones, muchas veces ejecutadas sobre el cuerpo humano, Piñera desarrolla en su narrativa una serie de desplazamientos, sustituciones y fragmentaciones que confrontan al lector analítico con una polivalencia de significados. Si el estilo de Piñera, llano, asequible, a veces coloquial, nos aleja de la complicada sintaxis y retórica generalmente asociadas con el término «barroco», sus aventuras intelectuales, sus atrevidos conceptismos nos sitúan en un mundo predominantemente «barroco». En su excelente prólogo a una edición de los cuentos de Piñera, José Bianco, jefe de redacción de la revista Sur (en la cual publicó Piñera cuentos y reseñas durante su residencia en la Argentina, en los años cincuenta), establece sus conexiones con lo barroco:

El cuentista barroco trataría de zafarse de los cánones bastante arbitrarios de la narrativa tradicional, gozando de una libertad que se parece al vértigo; se detiene en el preciso instante en que podría conquistarla por completo, o sea, perderla para siempre. Juega con las ideas hasta que sus últimas prolongaciones dan la impresión de abolir las ideas que manejó al principio... Piñera, hombre barroco, siente el consabido desengaño barroco ante el destino del hombre; escritor barroco, lo manifiesta intelectualmente. Al absurdo del mundo responde con el humorismo ${ }^{10}$.

Es con estas consideraciones en mente cuando pasamos a analizar los textos «dobles» de Virgilio Piñera.

Aunque el tema del doble aparece implícitamente en algunos otros cuentos de Piñera, nos limitaremos aquí a cstudiar los que consideramos más importantes: de estos siete, dos proyectan la aparición del doble a una realidad onírica («Una desnudez salvadora» y «Proyecto para un sueño»);

\footnotetext{
${ }^{9}$ Rogers, p. 173.

10 Virgilio Piñera, El que vino a salvarme (Buenos Aires: Sudamericana, 1970), pp. 9-10.
} 
cuatro se ocupan de la mutilación del cuerpo («Las partes», «La cara», «El caso Acteón» y «La caída»); el último, «El que vino a salvarme», resulta en la muerte del narrador. Todos presentan al doble como reflejo y todos están narrados en primera persona. Por su calidad de «sueños», los dos primeros resultan más asequibles. En ambos, el narrador se salva de una muerte segura a manos de su doble. En «Una desnudez...» se establece la relación narrador-doble a través de detalles significativos: «Estoy durmiendo en una especie de celda... Debo confesar que tengo frío. No es invierno todavía, pero yo estoy desnudo... De pronto alguien me saca de mi sueño. Medio dormido todavía, veo parado frente a mí a un hombre que, como yo, también está desnudo» ${ }^{11}$. La desnudez, que primero parece ser un detalle arbitrario, es la clave a la relación espejo entre estos «dos». Las frases «frente a mí» y «como yo», insertadas casualmente, le dan más peso a la proyección del doble; sin embargo, podría decirse que esta presencia es incorpórea, ya que, sin armas, el doble se siente incapacitado para matar al narrador. En este escueto texto, la aparición del doble es casi un chiste, y la confrontación entre narrador y doble no le impide al primero continuar su sueño. Aunque mucho más complicado en su trama, «Proyecto...» usa, básicamente, la misma relación espejo entre narrador y doble. Dos «absurdos» motivos dominan las acciones del narrador: uno, al que denomina como «pretexto», es, nos dice, «llevar a mi compañero unas cartas que éste había recibido dirigidas a mi nombre»; el otro, el verdadero, es que este «compañero», agradecido por sus servicios, le pague un café con leche y unas tostadas (pp. 43-44). Aunque el hambre y la miseria no son temas pueriles en la obra de Piñera, sino manifestaciones de una realidad vivida, los elementos fantásticos desplazan las necesidades cotidianas: lo que importa aquí es la proyección de un «otro yo» fuerte, violento y peligroso: el «compañero» camina «con vigor increíble» mientras el narrador le seguía «con muchísimo trabajo». Después de varias peripecias en una casa de interminables galerías, y de la repetición del motif del doble (se sugiere que un siniestro enano y un portero son la misma persona, hay dos mujeres y también dos policías), el «compañero» resbala y cae al fango, tratando de arrastrar consigo al narrador. La intervención de los dos policías le salva de tal suerte, y «la más alta autoridad» expulsa al «compañero» de la ciudad. Después de la sentencia, el narrador nos dice: «Yo saludé a todos y al pasar frente a un espejo me cubrí el rostro» (p. 50). Pero aunque quiera evitar su reflejo, su doble, su «compañero», el narrador lo vuelve a ver, esta vez junto a

\footnotetext{
11 Virgilio Piñera, Cuentos Madrid: Alfaguara, 1983), p. 23. Toda referencia a esta edición será anotada en el texto.
} 
un nuevo doble, que es, absurdamente, un chino. A su vez, este nuevo doble repite las acciones del anterior, tratando de apunalar al narrador. Se repite el rescate y se condena al «compañero» al exilio, «con prohibición absoluta de retorno» (p. 50). En ambos textos, el conflicto de la fragmentación del «yo» se resuelve con la eliminación del «otro yo» nocivo. En «Una desnudez...», la ausencia de armas impide el asesinato; en «Proyecto...», figuras paternas (las cuales podrían a su vez ser interpretadas como otras fragmentaciones del «yo») protegen al narrador. Ambos textos terminan en una nota absurda, ya que el narrador del primero sigue roncando plácidamente y el del último recuerda su frustrada merienda de café con leche y tostadas.

En «Las partes», el doble se manifiesta bajo la máscara de un «vecino» a quien el narrador ve aparecer repetidas veces desde su puerta, separada de la del vecino por un largo pasillo (es como si hubiera un espejo al final de éste). Una larga capa cubre el cuerpo del «vecino», cuerpo que va esfumándose, bajo la capa, con cada nueva aparición. Cuando el narrador penetra el espacio de su «vecino», descubre lo siguiente:

Clavados con enormes pernos a la pared se veían las siguientes partes de un cuerpo humano: dos brazos (derecho e izquierdo), dos piernas (derecha e izquierda), la región sacrocoxígea, la región torácica, todo imitando graciosamente a un hombre que está de pie como aguardando una noticia. No pude mirar mucho tiempo, pues se escuchaba la voz de mi vecino que me suplicaba colocar su cabeza en la parte vacía de aquella composición (p. 31).

Después de ejecutar el pedido, el narrador termina el texto con la siguiente oración: «Y como ya la capa no le sería de ninguna utilidad, me cubrí con ella para salir como un rey por la puerta.» Imposible no «ver», en pedazos, la imagen de un Cristo crucificado (imagen que se repetirá en La carne de René). El tono humorístico, irreverente, grotesco, el adverbio "graciosamente», aquí utilizados para describir un cuerpo descuartizado, ayudan a que el texto opere como una metáfora de la reconstrucción del «yo». El objeto de mediación, la capa, pasa a cubrir el cuerpo entero del narrador, ya liberado de su doble y en control. Este tipo de relación sadomasoquista también se manifiesta en "La cara». El narrador, quien se describe como novelista, recibe una llamada telefónica de un desconocido, quien confiesa que su cara «tenía un poder de seducción tan poderoso que las gentes, consternadas, se apartaban de su lado como temiendo males irreparables» (p. 88). Hace tiempo que nadie le ve la cara. Desarrollan

${ }^{12}$ El tema de la ceguera se manifiesta también en «Oficio de tinieblas» y en «El cambio», Cuentos, pp. 21-22 y 33-36. 
estos dos personajes una amistad «a través del hilo del teléfono»y, poco a poco, se van intercambiando los papeles a medida que el narrador, obsesionado por la idea de «la cara» del otro, le suplica que se conozcan para poder «conversar frente a frente en las tinieblas». La relación espejo se precipita entre estos «dos», que ya no pueden existir el uno sin el otro: «El no podía negarme nada, así como tampoco yo podía negarle nada. El encuentro tuvo lugar en su casa» (p. 92). El texto termina con la tercera y definitiva visita: «Una vez que estuve sentado en mi sillón le hice saber que me había saltado los ojos para que su cara no separase nuestras almas, y añadí que como ya las tinieblas eran superfluas, bien podrían encenderse las luces» (p. 96). La unión de estos dos elementos aparentemente opuestos se consigue a través de una relación negativa: uno no puede ver, el otro no puede ser visto ${ }^{12}$. Resultan así estos dos ser una sola entidad, margina$\mathrm{da}, \mathrm{y}$, de hecho, inexistente. $\mathrm{El}$ «no ver» es una manera de «no conocer» a ese «otro yo» seductor y peligroso o de conocerlo sólo con la imaginación. Tales mutilaciones del cuerpo expresan la rebelión del escritor ante la condición humana, ser y ser un cuerpo: «... Piñera se desquita con el cuerpo de los tormentos que éste le hace padecer. Metáforas de su aversión al cuerpo, o de su amor contrariado, son las ingeniosas y burlonas mutilaciones a que lo somete en sus relatos, las antropofagias individuales o recíprocas» ${ }^{13}$.

En «El caso Acteón», la mutilación es recíproca, y el narrador y su doble también terminan siendo una sola entidad. El título nos remite a su referencia clásica: Acteón, por casualidad, sorprende desnuda a la diosa Artemis cuando ésta se disponía a bañarse y, como castigo, Artemis lo transforma en ciervo; Acteón huye asustado, pero sus propios perros lo persiguen y lo despedazan a mordiscos ${ }^{14}$. Al principio de «El caso...», un hombre, «el señor del sombrero amarillo», invita al narrador a formar parte de «la cadena Acteón». Tal enunciación forma parte de un misterioso código al cual el narrador tiene total acceso ${ }^{15}$. Mientras dialogan uno frente a otro, cada uno va hundiendo una mano en el pecho del otro. El «señor» ofrece «las dos razones del caso Acteón»: la primera produce un desplazamiento del título, ya que «también aquí en Cuba... puede darse con toda propiedad el caso Acteón»; la segunda es que no es posible «marcar, delimitar, señalar, indicar, precisar... dónde termina Acteón y dónde comienzan sus perros» (pp. 26-27). Piñera utiliza el mito de Acteón ingeniosamente, sacándole provecho a sus elementos intrínsecos (el hom-

13 José Bianco, «Prólogo», véase nota núm. 10.

${ }_{14}$ Edith Hamilton, Mythology (Nueva York: New American Library, 1942), pp. 255-256.

${ }^{15}$ Es posible que a un nivel de significado haya una conexión con las populares «cadenas religiosas». 
bre es inocente, pero es condenado a una muerte absurda por una deidad, femenina además), pero también manipulándolos a su manera. En el universo piñeriano, la victoria y el triunfo no existen. Por eso, «los perros quedarían en una situación de inferioridad respecto de Acteón» si sobreviven. Pero como no hay límites entre Acteón y sus perros, entre el narrador y el «señor», entre el «yo» y su doble, «esos perros serán devorados también... por Acteón». Y termina el texto: «... como acompañábamos igualmente la palabra a la acción (hubiera sido imposible distinguir entre una y otra voz: mi voz correspondía a su acción; su acción a mi voz), sucedía que no hacíamos una sola masa, un solo montículo, una sola elevación, una sola cadena sin término» (p. 27). La relación verdugo-víctima se complica, ya que al modificar el escritor el mito de Acteón, las funciones de «devorador»y «devorado» son intercambiables entre las dos partes de este «montículo» o «elevación». La imagen fálica corresponde quizá al tema de la homosexualidad, tema que también se manifiesta en «La caída». En este texto, dos hombres, atados por una misma cuerda, caen de una altura de tres mil pies. Se establece la relación espejo entre el narrador y su «compañero» al quedar los dos «frente a frente» antes de despeñarșe. Mientras que el narrador quiere protegerse los ojos, el «compañero» teme perder «su hermosa barba, de un gris admirable de cristal gótico» (p. 14). Cada uno le cubre la parte más preciada al otro. El narrador describe la vertiginosa caída y el despedazamiento de los dos cuerpos:

Es verdad que a trechos... una parte de nuestro cuerpo se separaba de nosotros; por ejemplo, en cinco trechos perdimos: mi compañero, la oreja izquierda, el codo derecho, una pierna (no recuerdo cuál), los testículos y la nariz; yo, por mi parte, la parte superior del tórax, la columna vertebral, la ceja izquierda, la oreja izquierda y la yugular (pp. 14-15).

Quedan al final, sobre el césped, los ojos y la barba. Mientras que el narrador puede «ver» y narrar, el «compañero» sólo conserva la barba, que, aunque símbolo de masculinidad, resulta inoperante. Lo sexual queda anulado (sin testículos), mientras que predomina lo intelectual, el sentido de la vista, que permite conocer y analizar el mundo. Si se consideran a estos «dos» como uno, se podría sugerir que en este texto el escritor trata de integrar dos partes conflictivas de su psique: la sexual y la intelectual (ojos y barba), pero sólo logra hacerlo neutralizando la más conflictiva: la sexual.

Como La carne de René, «El que vino a salvarme», publicado en la década de los sesenta, marca un rompimiento con el tratamiento del doble en los cuentos que hasta ahora hemos analizado. En este texto, un viejo de noventa años nos cuenta su obsesiva preocupación no con su propia 
muerte, sino con la idea de controlar su muerte, de saber cuál será el momento preciso en que va a morir. La fijación del narrador se remonta a una experiencia de juventud: en un baño público vio a dos hombres que degollaban a un tercero: «... el tipo asesinado en el servicio sanitario supo, así de pronto, cuál sería su hora... Entre su exclamación desesperada y la mano que accionaba la navaja para cercenarle el cuello, supo el minuto exacto de su muerte» (p. 312). En el universo piñeriano, las imágenes carcelarias se producen en textos tan diversos entre sí como «El filántropo», «En el insomnio», «El conflicto» y «El infierno». En «El que vino...», la muerte opera como fuerza liberadora, como fin a la prisión del cuerpo y de la vida. Esta muerte se proyecta a la imagen del doble, el «extraño» al cual alude el título, cuyo papel de «salvador» lo relaciona a la imagen de Cristo. El narrador descubre al «extraño» a través del espejo. Tal imagen está intercalada con la de una fotografía de su padre muerto: «Desvié la vista de la foto e inconscientemente la puse en el espejo del ropero que está frente a mi cama. En él vi reflejada la cara de un hombre joven...» (p. 316). Si se analiza este proceso como uno de identificación, se podría sugerir que el narrador se identifica con su padre (su «yo» muerto) y con el «extraño» (su «yo» joven). Estas dos fragmentaciones del «yo» se entremezclan, convirtiéndose en una sola entidad: «Volví de nuevo a mirar la foto y creí advertir que la cara de mi padre estaba como enfurruñada, es decir, la cara de mi padre por ser la de él, pero al mismo tiempo con una cara que no era la suya, sino como si se la hubiera maquillado para hacer un personaje de tragedia» (p. 316). La idea de la máscara es importante, ya que sólo a través de ésta pueden comunicarse los personajes piñerianos. La confrontación final del narrador con su doble resulta en la repetición de la escena de la cual fue testigo en su juventud: «Cuando la navaja se hundió en mi yugular, miré a mi salvador, y entre borbotones de sangre, le dije: "Gracias por haber venido"» (p. 316). La aniquilación del narrador por el doble es radicalmente diferente de la exposición del doble en los relatos anteriores; en su tratamiento del tema, se aproxima a La carne de René, texto que pasamos a analizar, y también al ya mencionado «El otro yo», que se discutirá más adelante.

Esbozado en los cuentos, el tema del doble adquiere mayores dimensiones en La carne de René, novela en la cual los dobles barrocos se multiplican a medida que avanza el complicado argumento. Se podría decir que es una novela de aprendizaje al revés, al final de la cual el héroe parece aceptar, de manera pasiva, su posición en el mundo (un mundo absurdo regido por principios absurdos). Difícil es aceptar la opinión de José Rodríguez Feo, quien interpreta el epílogo didácticamente: «... lo que logramos verificar, como René al término de su aventura, es que somos de 
carne y hueso, más de carne que de hueso, que es la lección y la moral de este libro magnífico y valiente» ${ }^{16}$. Si aceptamos que La carne... es realmente una alegoría, como sugiere Rodríguez Feo, tendríamos que aceptar que la Conspiración Secreta es razonable y que, como indican sus preceptos, «la carne» existe sólo para ser sacrificada. La claudicación de René, su residencia permanente en la Sede de la Carne Acosada, es prueba de la actitud determinista y pesimista de Piñera: como sus dobles, René tiene que cumplir con un destino cruel y absurdo.

Al principio de la novela nos enteramos de que el padre de René, Ramón, es el jefe de una conspiración que defiende «la Causa del Chocolate» ${ }^{17}$. Como le explica Ramón a su inocente hijo: «Lo que defendemos es la idea del chocolate; no el chocolate en sí... Te confieso que nos harta el chocolate; tu mismo abuelo sonreía socarronamente cuando le hablaban del chocolate, lo que no obsta para que pasase toda su vida apoyándolo..., $y$, finalmente, ofreciendo su carne en aras del mismo» ${ }^{18}$. La imagen de la carne sacrificada se repetirá a través del texto. Las experiencias vitales de René, sus «ritos de pasaje» (tiene veinte años), serán delimitados por una serie de encuentros con diferentes dobles que, finalmente, lo llevarán a un triste encuentro consigo mismo. Los dos primeros dobles son de papel. René descubre que el cuarto privado de su padre es una especie de gabinete de dentista, una sala de tortura en la cual Ramón se flagela sistemáticamente, práctica común para los adictos a «la Santa Causa del Chocolate». Hay allí un cuadro al óleo cuyo tema es el Martirio de San Sebastián: «Aquel San Sebastián sacaba flechas de un carcaj... y se las iba clavando en el cuerpo... René estaba fascinado... Acercóse todavía más... Retrocedió espantado: ¿la cara allí pintada no era acaso la suya propia? ¿Aquel Sebastián no era René?» (pp. 32-33). Este Sebastián-René disfruta de su martirio, sonríe: su función es didáctica, ya que Ramón quiere preparar a su hijo para el sacrificio de la carne. Horrorizado, René se refugia en casa de una vecina viuda. Este primer encuentro resulta en la frustrada seducción del muchacho por la mujer, quien trata a toda costa de excitarlo sexualmente, optando, como último recurso, por mostrarle un álbum de dibujos anatómicos. René reacciona sintiendo frío, terror, recordando el Martirio de San Sebastián. El padre viene al rescate y se lleva a René a casa. Dalia y Ramón funcionan como antagonistas, contendientes

\footnotetext{
${ }_{16}$ «Una alegoría de la carne», Ciclón, 1, núm, 1 (enero 1955), p. 43.

17 La presencia del chocolate en este contexto nos refiere a Despair, de Nabokov, como posible influencia. En este texto, el burgués Hermann, fabricante de chocolate, se encuentra con su doble, el vagabundo Félix.

18 Virgilio Piñera, La carne de René (Buenos Aires: Siglo Veinte, 1952), p. 39. Toda referencia a esta edición será anotada en el texto.
} 
por «la carne de René»; pero si a la primera lectura parecería ésta una batalla entre Eros y Thanatos, se podrá comprobar más adelante que la mujer es también un elemento negativo (incluso repulsivo). Al día siguiente, Ramón lleva a su hijo en tren a la Escuela del Dolor, pero antes le anima a hojear el álbum de Dalia: «Entonces [René] abrió de nuevo el álbum, y como quien asiste a su propia ejecución... clavó sus ojos en la figura primera. Alguien había "retocado" dicha figura. El hombre aparecía en la misma posición, pero decenas de flechas se clavaban en su carne, en tanto que la cara no era otra que la de René mismo» (p. 56). Los dobles de papel tienen como función presentar el motif de la aversión al cuerpo y anunciar a los siguientes, los cuales serán, como se verá más adelante, de yeso, quizá de plástico y, finalmente, de carne y hueso. También nos permiten aquilatar el temperamento sensible y obsesivo de René y su incapacidad de sustraerse de su medio y de escapar a su destino. Es preciso señalar que la vulgaridad y falta de imaginación de Dalia son cualidades que acusan, desde un principio, la imposibilidad de la relación hombremujer.

En la Escuela del Dolor se enseña no sólo a tolerar, sino también a desear las torturas físicas. En su estudio sobre la evolución del concepto de la prisión moderna, Foucault muestra los paralelismos entre la filosofía y práctica de las instituciones penales y la historia intelectual europea. La Escuela del Dolor de Piñera, de hecho una prisión, representa el modelo propio del siglo XVIII:

The historical moment of the disciplines was the moment when an art of the human body was born, which was directed not only at the growth of its skills..., but at the formation of a relation that in the mechanism itself makes it more obedient as it becomes more useful... A «political anatomy», which was also a «mechanics of power», was being born; it defined how one may have a hold over others' bodies, not only so that they may do what one wishes, but so that they may operate as one wishes... Thus discipline produces subjected and practised bodies, «docile» bodies ${ }^{19}$.

A tales propósitos de indoctrinación, cada estudiante de esta «escuela» tiene en su cuarto un doble de yeso, cuyo "dócil» cuerpo muestra el resultado de los procesos de «la mecánica del poder». En el baño, detrás de una cortina negra, encuentra René a su doble:

Lo que estaba tras la cortina era una reproducción consumada del propio René en el trance de la crucifixión. La reproducción se inspiraba en la

19 Discipline and Punishment. The Birth of the Prison, trans. Alan Sheridan (Nueva York: Vintange Books, 1979), pp. 137-138. 
crucifixión de Cristo, pero el escultor hubo de introducir una modificación capital: en vez de la patética y angustiada faz del Cristo, ésta en yeso de René se ofrecía no caída sobre el pecho, sino muy derecha, en tanto que la boca mostraba una risa de persona enteramente satisfecha (p. 71).

Un erotismo malsano se vislumbra a través de la yuxtaposición del placer y el dolor físicos en las figuras del San Sebastián y del Cristo. La atmósfera enrarecida de la Escuela se percibe plenamente en una escena orgiástica en la cual el director, Mármolo; su sacerdote, Cochon (cuyo nombre significa «cerdo» en francés), y los alumnos más avanzados tratan de ablandar «la carne de René», endurecida y rebelde ante el dolor físico. René se niega a entregarse a la absurda lógica de la Escuela y a participar de sus actividades. Para convencerlo y «ablandarlo», todos lamen su cuerpo desnudo. Se llama a Roger, excelente alumno, cuya técnica nos recuerda la escritura del aparato de Kafka (en su texto «In the Penal Colony»): «Igual que probamos una y otra vez el punto de la pluma..., así Roger sacó su lengua, y tomando un dedo del pie de nuestro héroe, la aplicó una vez y otra a fin de cerciorarse de la bondad de su punta... Roger se asemejaba a esos calígrafos que pasan su pluma por los bordes del papel» (p. 121). Se podría sugerir que el texto de Kafka está insertado en esta escena, que funciona como una parodia de la tortura. Aunque posible víctima, René también se asemeja al explorador; Mármolo y Cochon son «dobles» de la figura paterna (en Kafka, el oficial y el antiguo comandante): «While the visitor to the penal colony... refuses to accept the principle, represented by the machine, that guilt characterizes the human condition and punishment must follow, the officer... sacrifices himself to establish the validity of a metaphysics of accountability» ${ }^{20}$. (En La carne..., la inmolación del padre, capítulos más adelante, establece la validez de un código absurdo, que a su vez hereda el hijo.) En esta escena, es necesario que el ritual de ablandamiento llegue a su clímax. Como los esfuerzos de estos «verdugos» resultan ineficaces, se destruye al doble, al sonriente Cristo crucificado:

Uno de los lamedores, borracho perdido, se obstina en ablandar una pierna del doble [de René] y... en un acceso de furor habíala pateado hasta hacerla saltar en pedazos. Esta fue la señal para el descuartizamiento... Entonces aquellos muchachos se dejaron caer sobre los fragmentos, y sacando sus sexos, los rociaron abundantemente (pp. 126-127).

El clímax (ya que no puede ser sexual) resulta en la muerte simbólica de René y en la profanación de su «cadáver». En su nueva vida, ya fuera

\footnotetext{
${ }^{20}$ Kurt J. Fickert, Kafka's Doubles (Berne: Peter Lang, 1979), p. 59.
} 
de la Escuela, su próximo doble funcionará estrictamente como un fetiche. La iniciación sexual de René es tan grotesca como su iniciación a los ritos del dolor, y tiene lugar en el apartamento de Dalia. Se presenta la escena como el reverso de la orgía de «ablandamiento», ya que lo que quiere Dalia (cuya profesión es maestra) es que «la carne de René» se endurezca: «Ella sintió... que las carnes de René se iban endureciendo lentamente... En consecuencia..., extinguió la roja luz de la lamparilla. Por su parte, el cerebro de René vio una mordaza y las frías tinieblas» (p. 173). Al despertar René en la cama de la mujer al otro día, siente «el mismo gusto amargo en la boca y el mismo dolor de cabeza» que sentía en la Escuela. En la bañadera, descubre René a su doble, un maniquí calvo, cuya cara tenía «sus mismos rasgos, su misma boca y hasta los mismos ojos grises y las arqueadas cejas» (p. 177). Ante su horror, Dalia le dice risueñamente: «Ahora habrá que guardarlo todo en sus cajitas. A él lo envolveré en papel de celofán; pondremos la peluca en su cajita y a Fifo en su estuche de terciopelo...» (p. 180). La personificación del pene (Fifo) resulta en la objetivación de René, cuya «carne» cumple una función estrictamente sexual. El miedo a ser devorado, aniquilado, consumido, castrado se realiza aquí plenamente a través de la emasculación del doble y la relación que tiene Dalia con éste, relación que trata de imitar en vivo con René. La identificación de este doble con el Cristo de yeso es evidente. A través de la posesión y control del doble, se comprueba que «la carne de René» es presa igualmente vulnerable a los abusos de Mármolo y sus secuaces y a los de Dalia.

Mientras que los dobles hasta aquí descritos son reproducciones de René, ya sea en dos o en tres dimensiones, los que encontraremos ahora serán «de carne y hueso». Al abandonar el apartamento de Dalia, René «vio que cuatro maniquíes le cerraban el paso. Eran cuatro dobles de su propia persona» (p. 183). El hecho se complica, ya que estos «maniquíes» (dos hombres, una mujer y una niña) son personas que han sido contratadas por la Conspiración para protegerle la vida a René. En este mundo de perseguidores y perseguidos, la paranoia de René obedece a una realidad, pero lo absurdo de la personificación de los cuatro dobles le permite creer más adelante que han sido producto de una alucinación. Aunque oficialmente estos dobles alegan que su función es «proteger» la vida de René, trabajan para la Causa de la Carne, cuyo propósito es la aniquilación de René como entidad libre e independiente. La multiplicación de los dobles ocurre al mismo tiempo que el asesinato del padre (quien, por supuesto, tenía también su doble); oficialmente, René es ahora el Jefe de la Causa. Aunque trata de evadirse, trabaja y estudia, lleva una vida «normal»; un día viene a buscarlo su «otro yo»: 
Miró de nuevo hacia la esquina y «aquello» levantó la vista y le miró fijamente. No, «aquello» tenía vida real; era de carne y hueso como él y no meras alucinaciones. «Aquello» no iba a desaparecer... Esto era definitivo y sólo su muerte lo cambiaría en otra cosa.

Desvió la vista, pero «aquello» cambió de posición y apuntóle con los ojos como si fueran dos pistolas, al tiempo que echaba a andar, invitándole a seguirle (pp. 246-247).

Este doble hace todo lo que no puede hacer René. Contratado por la Sede de la Carne Acosada, está listo a confrontar cualquier peligro, a cometer cualquier acto; una de las pruebas que ha pasado para obtener este trabajo ha sido asesinar a un hombre a sangre fría, comportándose, en sus propias palabras, «como un machito» (p. 252). El hecho de que este doble sea todo lo que René no puede y no quiere ser, sitúa al texto «al revés», o sea, constituye una inversión del canon de la literatura del doble: «One of the recurrent preoccupations of doble literature is with the need to keep a suppressed self alive, though society may insist in annihilation..., a truly insubordinate perhaps illusory, original and fundamental self...» ${ }^{21}$. En el texto de Piñera, el «doble» de René representa los valores de «la sociedad», y es creado por ella, mientras que el «yo» ha sido sistemáticamente aniquilado: la progresiva multiplicación de los dobles ha logrado borrar la identidad de René. La culminación de este proceso sucede al morir este último doble, «el machito», a quien irónicamente se entierra bajo el nombre de René. Aunque prisionero de su destino (es Jefe de la Causa del Chocolate y vive en la Sede de la Carne Acosada), la insubordinación de René consiste en no participar en las actividades de la Conspiración. Al final de la novela, frente a un espejo, sobre una báscula, en la que comprueba que «su carne marchaba, pues había aumentado su peso en dos kilos y medio» (p. 285), René se convierte en el doble de sí mismo, en «la carne de René».

Es necesario señalar algunos detalles pertinentes antes de proseguir: aunque no ha sido la intención de este ensayo proponer una lectura política de la narrativa de Virgilio Piñera, es preciso subrayar que el proceso de la autocensura ha sido uno imprescindible en la producción literaria de este escritor. Como algunos de los cuentos, La carne de René fue publicada en la Argentina; pero la atmósfera de persecución, los asesinatos arbitrarios, la constante presencia de la tortura corresponden al clima político de Cuba durante los años cincuenta. También habría que agregar que si bien Piñera se integró a la Revolución cubana de 1959 a raíz de su triunfo, su obra posterior refleja cierta ambigüedad respecto de la adaptación del individuo a la sociedad. El hecho de que la trama de Pequeñas maniobras (1963)

\footnotetext{
${ }^{21}$ Albert Guerard, Stories of The Double (véase nota núm. 1), p. 2.
} 
suceda antes de 1959 «redime» la novela, aunque haya sido producida bajo un régimen político en el cual el narrador (marginado, enajenado, prototipo del «pícaro homosexual») ${ }^{22}$ no tendría cabida. La reseña de Rogelio Llopis en Casa de las Américas, llena de reparos y advertencias ( «No olvide el lector que la acción de la novela discurre en plena dictadura batistiana») ${ }^{23}$ parecería corroborar esta opinión. La última novela de Piñera, Presiones y diamantes (1967), refleja su obsesión con el paranoico mundo de las conspiraciones secretas a través de un elaborado código de significados ocultos, que obedecen a una velada crítica de la realidad política cubana durante la década de los sesenta:

El novelista puede todavía evadir su responsabilidad con el presente, y aun cuando éste queda aludido, los personajes no censuran -al menos explícitamente - ningún aspecto de la revolución que les parezca reprochable. La crítica y/o el descontento apelan al subterfugio, con lo cual pretenden borrar del texto cualquier noción de referencialidad comprometedora. Es en este clima de libertad intelectual supervisada que Virgilio Piñera escribe Presiones y diamantes ${ }^{24}$.

Se podría sugerir que, amenazada la «libertad intelectual supervisada», el escritor cubano se vio obligado a perfeccionar las técnicas de «subterfugio» en su obra posterior. Publicados póstumamente en 1987, y en su mayoría escritos durante la década de los setenta, los textos recogidos en Un fogonazo merecen ser leídos desde esta perspectiva, pero eso daría lugar a otro ensayo; para terminar éste, nos concentraremos en el tema del doble, magistralmente expresado en uno de ellos.

Los cuentos de Un fogonazo reflejan preocupaciones constantes en la narrativa de Virgilio Piñera: en «Belisario», un tigre que ha vivido como ser humano toda la vida ( «Su mujer lo adoraba... Para ella no tenía nada de tigre, excepto la anatomía») ${ }^{25}$, recobra su identidad a la hora de la muerte al lanzar «un temible rugido»; en «El crecimiento del señor Madrigal», un hombre de ochenta años «tuvo un parto feliz», al dar a luz su propio cadáver (p. 12); «La muerte de las aves» funciona como metáfora de la creación literaria («La ficción del escritor, al borrar el hecho, les

${ }^{22}$ Véase E. Méndez y Soto, «Piñera y el tema del absurdo», Cuadernos Hispanoamericanos, 299 (mayo 1975), pp. 448- 453

${ }^{23}$ Véase nota núm. 2. Otra reseña «ambigua» es la de César López, «Chiclets, canasta, presiones y diamantes», Unión (La Habana), 6, núm. 3 (julio-septiembre 1967), pp. 131-134.

${ }^{24}$ Perla Rozencvaig, «Presiones y diamantes: lectura inversa», Linden Lane, 4, núm. 1 (enero-marzo 1985), p. 14.

${ }^{25}$ Virgilio Piñera, Un fogonazo (La Habana: Letras Cubanas, 1987), p. 38. Toda referencia a esta edición será anotada en el texto. 
devuelve la vida. Y sólo con la muerte de la literatura volverán a caer abatidas», p. 6). En «el otro yo», texto que da comienzo a este ensayo, la ironía funciona como una constante en el desarrollo de la trama: se trata de un hombre, el señor $\mathrm{X}$, que, por razones que no se explican, decide hacerse de un otro yo, fielmente reproducido por eminentes «tecnólogos»; este $\mathrm{X}$ mecánico sobrevive al señor $\mathrm{X}$, pero, al ser afectado por una sustancia radiactiva, adquiere manchas e imperfecciones; como resultado, «todos dijeron en público que quien había muerto no había sido el señor X, sino el X mecánico» (p. 61). Desde el primer párrafo, la calidad autorreflexiva del texto se manifiesta, ya que el otro yo «no sería el alter ego que suelen usar los escritores en sus narraciones» (p. 57). También se establecen elementos de mediación entre el señor X y el X mecánico, o sea, la tecnología, que puede reproducir su persona, y su dinero, que le permite pagar por tal servicio. A diferencia de los cuentos discutidos anteriormente, en éste el narrador nos cuenta no su propia historia, sino la del anónimo señor $\mathrm{X}$; se produce, pues, un desplazamiento de la experiencia del doble, que a su vez crea el alter ego que se rechazó en un principio. Si en los cuentos previos y en La carne de René el tema del doble se relacionó a problemas de identidad, a la aversión hacia el cuerpo y a una homosexualidad no disimulada ${ }^{26}$, la idea principal que se explora aquí es la de la inmortalidad. El conflicto que se crea entre el señor X y su otro yo obedece estrictamente a la inminente muerte del primero y a la supuesta indestructibilidad del segundo: «Las relaciones entre ambos se complicaban... porque $\mathrm{X}$ conocía que no sobreviviría al $\mathrm{X}$ mecánico y, por ende, el X mecánico tenía la certeza de que sobreviviría al X humano» (p. 58). Pero cuando el señor $X$ decide deshacerse de su otro yo, los tecnólogos le responden: «Nunca destruimos lo que creamos. Nuestras creaciones son indestructibles» (p. 60). Tal afirmación se deconstruye cuando el X mecánico empieza a deteriorarse como resultado de la radiactividad. Los elementos de mediación que permitieron la creación de este otro yo resultan inoperantes en su destrucción: el dinero del señor $\mathrm{X}$ no sirve frente a la inflexible negación de los tecnólogos; por otra parte, la supuesta infalibilidad de los mismos queda anulada por la radiactividad. $\mathrm{Si}$ consideramos el texto como una metáfora del proceso creador (el señor $\mathrm{X}=$ el escritor, y el $\mathrm{X}$ mecánico $=$ su alter ego, personaje u obra), tendríamos también que discutir el papel de mediación que desempeñan

${ }^{26}$ La honesta y valiente actitud de Virgilio Piñera respecto de la homosexualidad durante una época intolerante y represiva puede apreciarse en su ensayo «Ballagas en persona», Ciclón, 1, núm. 5 (septiembre 1955), en el cual discute sin ambages la homosexualidad del poeta Emilio Ballagas, fallecido en 1954. 
los poderosos tecnólogos. Al final del texto resultan burlados, ya que, a causa de sus imperfecciones, la gente cree que el X mecánico es el señor $\mathrm{X}:$ «... como la pública opinión es un arma mortífera, la opinión particular de los tecnólogos se vio abolida por la opinión universal» (pp. 61-62). Es el receptor, entonces, quien determina la identidad, o validez, del producto (el X mecánico) no necesariamente su emisor (el señor X) o su mediador (los tecnólogos). En este contexto, «el otro yo» sustituye al «yo». Al identificar al producto creado con su creador («inmortal era el señor X en la voz de la opinión»), «el otro yo» resulta ser, como el arte, eterno (sujeto a «la radiactividad», al tiempo, a interpretaciones críticas). 
